\title{
Parvovirus and reproductive disorders in the pig. Glinical and serological study - Practical consequences
}

\author{
P. VANNIER ( ${ }^{1}$ ), J. LEUNEN $\left({ }^{2}\right)$ et J. P. TILLON ( $\left.{ }^{1}\right)$ \\ (1) Station de Pathologie porcine, B.P. $n^{0}$ 9, 2244o Ploufragan (France) \\ (2) Institut national de Recherches vétévinaires, \\ Groselenberg, 99, B II80 Bruxelles (Uccle) (Belgique)
}

\begin{abstract}
A serological survey made in France reveals a rather large diffusion of the Parvovirus among pig herds. 45.2 per cent of the analysed sera show a level of antibodies equal or superior to I/320e. Two routes of infection of the breeding animals are considered: the venereal route certainly plays an important part in the dissemination of the virus. After settlement of an immunity subsequently to a contamination of a herd, an infection can be started again with newly introduced breeding animals, the serum of which is devoid of Parvovirus antibodies. These clinical observations have been experimented on an S.P.F.pig in contact with in utero infected pigs exhibiting a progressively decreasing antibody level.
\end{abstract}

\section{A survey of the microflora specific of respiratory diseases in " minimal disease" and conventional pig herds}

\author{
M. KOBISCH (1), J. P. TILLON (1) et Y. LE TURDU ( $\left.{ }^{2}\right)$ \\ (1) Station de Pathologie Porcine, B.P. $n^{0}$ 9, 22400 Ploufragan (France) \\ ${ }^{(2)}$ Laboratoire de la Divection des Services vétérinaires \\ 8 , place du $74^{\mathrm{e}}$ R.I., 22000 Saint-Brieuc (France)
}

A survey of the microflora (mycoplasma and bacteria) associated to respiratory diseases in I I conventional and 23 "Minimal Disease" pig herds is presented. Mycoplasma suipnenmoniae is frequently isolated from SPF herds showing respiratory diseases; Mycoplasma hyorhinis is currently found in the lungs of pigs from conventional herds. The isolation of respiratory specific bacteria is more frequent in conventional herds. These results are interpreted.

\section{Pasteurella multocida pathogenesis in young swine. Attempts to obtain an acute bacterial swine pneumonia model}

\author{
J. P. RAYNAUD (1), G. BRUNAULT (1), C. MAIRE ( ${ }^{2}$ ), L. RENAUlT ( ${ }^{(2)}$ et P. PERREAU (3) \\ (1) Station de Recherche et Développement vétérinaive et Nutrition aninale \\ Pfizer International, 37400 Amboise (France) \\ (2) Laboratoives vétérinaires Sanders $S . A$., \\ I7, quai de l'Industrie, 9 I $_{2} 60$ Juvisy-sur-Orge (France) \\ ( $\left.{ }^{3}\right)$ Institut d'Élevage et de Médecine vétérinaire des Pays tropicaux, \\ Io, me Pierre-Curie, 94700 Maisons-Alfort (France)
}

Our objective was to develop in our laboratory a mode of acute bacterial swine pneumonia. The pathogenesis of 7 strains of Pasteurella multocida type $\Lambda$, was checked in mice intra-peritoneally, intra-nasally or after nebulization. 